Article

\title{
Intellectual Capital Performance of the Textile Industry in Emerging Markets: A Comparison with China and South Korea
}

\author{
Jian $\mathrm{Xu}^{1}{ }^{1}$ and Binghan Wang ${ }^{2, *}$ \\ 1 School of Management, Qingdao Agricultural University, Qingdao 266109, China; jianxusword@qau.edu.cn \\ 2 Business School, Lincoln University, Lincoln 7647, New Zealand \\ * Correspondence: wangbhlincoln@gmail.com
}

Received: 24 March 2019; Accepted: 17 April 2019; Published: 19 April 2019

check for updates

\begin{abstract}
In this study, the Value Added Intellectual Capital (VAIC ${ }^{\mathrm{TM}}$ ) and Modified Value Added Intellectual Capital (MVAIC ${ }^{\mathrm{TM}}$ ) models are utilized to analyze intellectual capital (IC) performance of the textile industry in China and South Korea during 2012-2017, and measure the contribution of IC sub-components to companies' performance. The results show that the aggregate IC positively affects earnings, profitability, and productivity of textile companies in China and South Korea. At the sub-components level, the contribution of capital employed efficiency (CEE) is the largest, followed by structural capital efficiency (SCE), and relational capital efficiency (RCE) in China's textile industry. In addition, Korea's textile industry relies heavily on CEE and human capital efficiency (HCE), while the contribution of RCE is relatively small. Finally, relevant policies are put forward to promote the sustainable development of the textile industry in these two emerging markets.
\end{abstract}

Keywords: intellectual capital; firm performance; textile industry; emerging markets

\section{Introduction}

The importance of intellectual capital (IC) is one of the most hotly debated issues in contemporary socio-economic development [1,2]. With the emergence of knowledge-based economy, IC is generally acknowledged as a driver of competitiveness and sustainability [3-7]. Moreover, IC investment is increasingly crucial to companies that seek to achieve productivity and efficiency gains [8,9]. According to the resource-based view (RBV), valuable and scarce resources (e.g., knowledge, information technology, and intellectual skills) can enable companies to gain sustainable competitive advantage and accelerate superior performance $[6,7,10]$.

Sustainability has long been a popular topic of discussion in academia [11-14]. Business sustainability is related to sustainable development, corporate social responsibility (CSR), and corporate citizenship [15]. In a broader context, social, environmental, and economic demands are viewed as the three pillars of business sustainability. In particular, Malinowska-Olszowy [16] stated that IC plays a critical part in the sustainable development of the textile industry. In order to achieve this, textile companies must stress the implementation of IC strategies and obtain unique competencies and skills in today's dynamic business environment $[17,18]$. As a traditional industry, we are more concerned in how textile industry effectively utilizes IC to achieve sustainable development in the knowledge-based economy.

Although the gap of textile production scale between China and South Korea is very large, the textile industry in the two countries has a similar development path [19].

After the Second World War, the textile industry in South Korea became one of the first industries to realize modernization [19]. From 1960s to 1990s, the textile industry, one of the major industries with 
significant employment, dominated a large percentage of the Korean economy [20]. In the late of 1990s, South Korea's textile industry began a transformation from labor-intensive into technology-intensive with production capabilities declining year by year. Today, textile production relies on imports from China as well as Association of Southeast Asian Nations (ASEAN) [21]. The Manufacturing Innovation 3.0 strategy was implemented to boost the manufacturing sector in 2014. Currently, the construction of China Korea Free Trade Area helps textile trades between the two countries achieve a win-win purpose.

China has the world's largest textile industry with more than 30\% market share [22-24]. This traditional industry increasingly rose after joining the World Trade Organization (WTO) in 2001 [24,25], which became one of the pillar industries of China's economy [26]. However, in 2013, the capacity was dropping gradually [19]. During 2012-2015, the growth rate of value added in the textile industry decreased from $12.2 \%$ in 2012 to $7 \%$ in 2015. In addition, its development among regions or enterprises is extremely unbalanced. In China's economic transition, the textile industry faces many pressures, such as high energy consumption, the unfavorable factors of domestic raw materials and low-end textile products from India, Pakistan, and other regions [27,28]. China's textile industry has experienced the institutional change and industrial restructuring [29]. The implementation of "One Belt One Road" initiative has brought new opportunities for China's textile industry [24,30]. What's more, the government unveiled the "Made in China 2025" plan that aims to transform China from a manufacturing giant into a world manufacturing power.

Therefore, it is obvious that the tracks of textile industrial development are similar between China and South Korea. That is, the textile industry in these two countries witnessed the booming growth and a decline in production capability. In recent years, Korea's labor costs have surged [31], while China's ongoing economic transformation is encouraging textile companies to hire and retain skilled and experienced employees. With different state and market economy systems, the impact of IC on firm performance might be different. Therefore, it is worthwhile to explore the role of IC in the textile industry in the two emerging markets.

The contributions of this paper are as follows. It is the first comparative analysis of the impact of IC on firm performance within the textile industry in emerging markets (i.e., China and South Korea). Most literature has mainly focused on one country or region, and little has been done on IC performance of this traditional industry in two countries. Second, the existing IC literature on textile industry is mainly descriptive summaries, lacking empirical research. Third, this study expands the extant literature and provides some valuable policy implications for the emerging economies in promoting the traditional industry. This study also benefits academics, policymakers, and business people who are interested in textile development in general.

The paper is organized into six sections. Following the Introduction, Section 2 presents a literature review and develops hypotheses. Section 3 focuses on the research methodology in this study. Empirical results are presented in Section 4, and the results are discussed in Section 5. Finally, Section 6 provides a summary and several policy suggestions.

\section{Literature Review and Hypotheses Development}

\subsection{IC Definition}

The extent literature offers many definitions of IC, and scholars have not yet reached a consensus [3,17,32-34]. For example, Stewart [35] defined IC as an intangible value generated for human being and resources. Sullivan [36] stated that IC is considered as company knowledge that can be converted into tangible profit. Bontis and Fitz-enz [37] advocated that IC includes intellectual material, knowledge, experience, intellectual property, and information that a company can use to create wealth.

Recently, the IC of an organization has been formed by its human capital (HC), structural capital (SC), and relational capital (RC) [6,38-41]. HC, a major capital, is related to employees' knowledge, experience, skills, and expertise that can increase company performance $[39,40]$. SC is the support or 
infrastructure that an organization provides for its HC [36]. RC, the most controversial element of IC, is related to the networks and internal and external relationships of an organization [36,39].

Different models are developed for measuring IC $[6,42,43]$. These methods are listed as follows: (1) Tobin' Q, (2) Economic value added (EVA) and market value added (MVA), (3) Skandia Navigator [44], (4) Intangible Assets Monitor [45], (5) Balanced Scorecard [46], (6) Value Added Intellectual Coefficient (VAIC $^{\mathrm{TM}}$ ) [47,48], and (7) Technology broker [49].

Compared with other IC measurements, the VAIC ${ }^{\mathrm{TM}}$ model is employed by most researchers because of its simplicity, which allows effective comparison across firms or countries [3,5-7,34,50-54]. In addition, the results are derived from audited financial information. The VAIC ${ }^{\mathrm{TM}}$ model is utilized to measure the IC efficiency of a firm: capital employed efficiency (CEE), human capital efficiency (HCE), and structural capital efficiency (SCE). CEE describes how much a company creates through one monetary unit invested in financial or physical capital. HCE describes how much a company creates through one monetary unit invested in human resources. SCE measures how much capital a company can create through SC.

The VAIC ${ }^{\mathrm{TM}}$ model still has some limitations. First, the data used in this model are historical data from financial statements that measure past IC rather than future value creation [53]. Second, some important elements of IC (e.g., RC and innovation capital) are neglected in this model. In order to overcome this limitation, Vidyarthi [7] and Nimtrakoon [55] modified the VAIC ${ }^{\mathrm{TM}}$ model by introducing market cost as RC. In addition, some researchers claim research and development (R\&D) costs should be recognized as a measure of innovation capital efficiency [6,51]. Third, it is inaccurate to consider that the salaries and wages in the income statement represent total employee costs [56,57]. Finally, it also assumes zero beginning and ending inventory. In this study, we modify the VAIC ${ }^{\mathrm{TM}}$ model incorporating one variable, relational capital efficiency (RCE), to assess IC efficiency, since better customer relationship and new customer acquisition are important for a company to succeed in the fierce market competition [58].

\subsection{IC and Firm Performance}

Various studies have assessed the relationship between IC and financial performance of companies. Janošević et al. [59] conducted a study in Serbia and found no significant relationship between operating revenue and the efficient use of IC. However, Jordão and de Almeida [60], using BM\&FBovespa companies, suggested that IC is positively related to earnings before interest, taxes, depreciation, and amortization (EBITDA). The findings of Dzenopoljac et al. [53] showed that structural and physical capital positively affect company earnings (measured through EBITDA) in the Arab region. Based on the data of Chinese agricultural listed companies during 2012-2016, $\mathrm{Xu}$ and Wang [61] found that earnings quality - measured through earnings before interest and taxes (EBIT) —is determined by CEE, HCE, and SCE. Therefore, we come to the following hypothesis:

Hypothesis 1 (H1). IC performance generates higher earnings in the textile industry in China and South Korea.

An early empirical study by Bontis et al. [62] revealed that SC has a great impact on business performance and $\mathrm{HC}$ is of significance regardless of industry type. A later study by Chen et al. [51], aimed at measuring the relationship between the value creation efficiency and market value as well as financial performance. The study found that firms with better IC efficiency yield greater profitability, measured through return on assets (ROA) and return on equity (ROE). Wang and Chang [63], based on the data of IT industry in Taiwan, found that IC elements have a direct effect on business performance measured through ROA and ROE, with the exception of HC. Yalama and Coskum [64] also proved the positive impact of IC on firms' profitability. Pal and Soriya [52] in the study of Indian pharmaceutical and textile industry argued that IC and profitability are positively associated. Nimtrakoon [55] in an empirical research found that IC is positively associated with margin ratio and ROA. Results also showed that CEE and HCE are the most influential value drivers for financial performance. Recently, 
Dzenopoljac et al. [53] found that physical capital and SC can significantly affect firms' profitability. Sardo and Serrasqueiro [34] also suggested that IC efficiency over the current period has a positive impact on the financial performance of high-, medium-, and low-tech European firms, measured by ROA. Smriti and Das [54] found that the positive relationship between CEE and profitability (measured through ROA) leads to the success of Indian firms. Sardo et al. [65], using the GMM system estimator, found that IC components provide a positive impact on financial performance of small and medium-sized hotels. Thus, we formulate the following hypothesis:

Hypothesis 2 (H2). IC performance generates higher profitability in the textile industry in China and South Korea.

IC is considered to be the driver of company efficiency in knowledge-based economies. The relationship between IC and productivity is not consistent. A study in Malaysia by Gan and Saleh [66] showed that companies with greater IC are more likely to have a more efficient productivity, and HC is a more significant factor in relation to productivity. However, Firer and Stainbank [67] studied the 65 South African publicly traded companies and found that IC performance has significant but negative explanatory power for company productivity. Similarly, based on 80 Taiwan listed technological firms, Shiu [68] used the VAIC ${ }^{\mathrm{TM}}$ model and revealed that there is a negative relationship between IC and productivity (measured by asset turnover). In addition, Pal and Soriya [52] observed that IC does not play any significant role in the productivity of Indian pharmaceutical and textile companies. Accordingly, our third hypothesis is stated as follows:

Hypothesis 3 (H3). IC performance generates higher productivity in the textile industry in China and South Korea.

China is the world's second largest economy after the U.S., while South Korea is one of the most successful emerging economies in recent decades. The two countries have some differences in their national culture and institutional systems, which could result in differences in the management of IC. Lin et al. [69] found that the national intellectual capital of South Korea is far ahead that of China, and that among five types of IC, Korea is comparatively better in HC and renewal capital while China is relatively better in market capital. The findings by Nimtrakoon [55] also show that four components of IC (i.e., CEE, HCE, SCE, and RCE) differ between Indonesia, Malaysia, Philippines, and Singapore. Therefore, we propose the following set of hypotheses:

Hypothesis 4a (H4a). The impact of IC on earnings is different in China and South Korea.

Hypothesis $\mathbf{4 b} \mathbf{b} \mathbf{H} \mathbf{b})$. The impact of IC on profitability is different in China and South Korea.

Hypothesis 4c (H4c). The impact of IC on productivity is different in China and South Korea.

\section{Methodology}

\subsection{Research Objectives}

The aim of this study is to examine the impact of IC on performance measurements using 29 and 37 textile companies in China and South Korea as the samples over the period 2012-2017. Companies with missing information or companies listed after 2012 were excluded from our samples. Chinese and Korean data were derived from the CSMAR and DataGuide database, respectively. For facilitating comparison, Korean Won was converted to Chinese Yuan according to the Chinese official intermediate exchange rate by the end of each year. The pooled OLS regression models were utilized on firm-level data for the analysis. 


\subsection{Variables}

(1) Dependent variables. Firm performance (Perf) was measured from three distinct aspects: earnings, profitability, and productivity. EBITDA was used for measuring companies' earnings $[53,59,60]$. In order to avoid skewness of data distribution, we used the logged value of EBITDA. ROA was used to measure companies' profitability and was calculated as:

$$
\mathrm{ROA}=\text { Net income/Average total assets }
$$

ROE measures a company's profitability by revealing how much profit a company generates with the invested money of shareholders. It is calculated as:

$$
\text { ROE }=\text { Net income/Average total equity }
$$

Assets turnover ratio (ATO) is the proxy for measuring the productivity of the textile companies [52,54,66-68]. It is calculated as:

$$
\mathrm{ATO}=\text { Revenue} / \text { Total assets }
$$

(2) Independent variables. Guided by previous literature reviews [3,6,7,34,51-54], the VAIC ${ }^{\mathrm{TM}}$ model was employed to measure IC efficiency. It consists of CEE, HCE, and SCE. VAIC is the sum of CEE, HCE, and SCE. The calculation of VAIC is summarized as follows:

$$
\begin{gathered}
\mathrm{VA}=\mathrm{W}+\mathrm{I}+\mathrm{T}+\mathrm{NI} \\
\mathrm{CEE}=\mathrm{VA} / \mathrm{CE} \\
\mathrm{HCE}=\mathrm{VA} / \mathrm{HC} \\
\mathrm{SCE}=(\mathrm{VA}-\mathrm{HC}) / \mathrm{VA} \\
\mathrm{VAIC}=\mathrm{CEE}+\mathrm{HCE}+\mathrm{SCE}
\end{gathered}
$$

where VA is the value added; $\mathrm{W}$ is wages and salaries; $\mathrm{I}$ is interest expenses; $\mathrm{T}$ is taxes paid; $\mathrm{NI}$ is net income; CE is capital employed, measured by the book value of the net assets of the firm; and HC is human capital, measured by salaries and wages of all employees.

The Modified Value Added Intellectual Capital (MVAIC ${ }^{\mathrm{TM}}$ ) model incorporates RC as a new variable, because maintaining a good relationship with customers and vendors is also important for a firm's success $[7,58,70]$. According to the MVAIC ${ }^{\mathrm{TM}}$ model, MVAIC is the sum of four efficiency parameters (i.e., $\mathrm{CEE}, \mathrm{HCE}, \mathrm{SCE}$ and RCE). The calculation of MVAIC is as follows:

$$
\begin{gathered}
\text { RCE }=\text { RC/VA } \\
\text { MVAIC }=\text { CEE + HCE + SCE + RCE }
\end{gathered}
$$

where RCE represents relational capital efficiency; and RC represents relational capital, measured by advertising expenditure of a company.

(3) Control variables. Based on existing literature [6,7,32,52,53,71], Lev (measured by the ratio of total debt to total assets) and Size (measured by the natural logarithm of total assets) were employed as the proxy used for the leverage of textile companies and the size of these companies, respectively.

\subsection{Models}

This study aims to examine the impact of IC (measured by VAIC and MVAIC) on the performance of textile companies in China and South Korea. VAIC and its three components were used in models (1) and (2), respectively. Furthermore, MVAIC and its components were employed as alternative IC 
indicators in models (3) and (4), respectively, for robustness check. The empirical models have been presented in Table 1. In addition, the mean differences in all variables used in this study were analyzed by $t$-test, which can be used to determine if two sets of data are significantly different from each other.

Table 1. Model's representations.

\begin{tabular}{|c|c|}
\hline Model & Functional Representations \\
\hline Perf = $f($ VAIC, Size, Lev $)$ & $\operatorname{Perf}_{i t}=\beta_{0}+\beta_{1}$ VAIC $_{i t}+\beta_{2}$ Size $_{i t}+\beta_{3} \operatorname{Lev}_{\text {it }}+\varepsilon_{\text {it }}$ \\
\hline Perf $=f(\mathrm{CEE}, \mathrm{HCE}, \mathrm{SCE}$, Size, Lev $)$ & $\begin{array}{c}\text { Perf }_{i t}=\beta_{0}+\beta_{1} \mathrm{CEE}_{\mathrm{it}}+\beta_{2} \mathrm{HCE}_{\mathrm{it}}+\beta_{3} \mathrm{SCE}_{\mathrm{it}}+\beta_{4} \text { Size }_{\mathrm{it}} \\
+\beta_{5} \operatorname{Lev}_{\mathrm{it}}+\varepsilon_{\mathrm{it}}\end{array}$ \\
\hline Perf $=f($ MVAIC, Size, Lev $)$ & Perf $_{i t}=\beta_{0}+\beta_{1}$ MVAIC $_{i t}+\beta_{2}$ Size $_{i t}+\beta_{3}$ Lev $_{\text {it }}+\varepsilon_{\text {it }}$ \\
\hline Perf $=f(C E E, H C E$, SCE, RCE, Size, Lev $)$ & 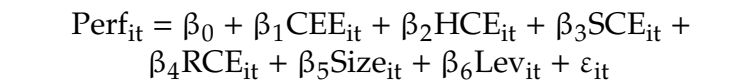 \\
\hline
\end{tabular}

\section{Empirical Findings}

\subsection{Descriptive Statistics}

Tables 2 and 3 provide detailed descriptive statistics for the textile industry in these two countries.

Table 2. Descriptive statistics of the textile industry in China.

\begin{tabular}{cccccc}
\hline Variable & $\mathbf{N}$ & Mean & Max & Min & Standard Deviation \\
\hline EBITDA & 156 & 8.2328 & 9.1005 & 6.3678 & 0.5130 \\
\hline ROA & 174 & 0.0317 & 0.1701 & -0.6415 & 0.0769 \\
\hline ROE & 174 & 0.0467 & 0.3066 & -0.9693 & 0.1297 \\
\hline ATO & 174 & 0.7050 & 2.3276 & 0.0350 & 0.3799 \\
\hline VAIC & 174 & 2.0509 & 35.3508 & -47.6166 & 5.2642 \\
\hline MVAIC & 174 & 2.0640 & 34.0456 & -47.6166 & 5.1949 \\
\hline CEE & 174 & 0.2350 & 0.5538 & -1.8399 & 0.2136 \\
\hline HCE & 174 & 1.3986 & 5.1618 & -46.7981 & 3.9297 \\
\hline SCE & 174 & 0.4173 & 35.3856 & -23.6518 & 3.3616 \\
\hline RCE & 174 & 0.0131 & 0.7683 & -1.3052 & 0.1210 \\
\hline Size & 174 & 9.4720 & 10.2050 & 8.5877 & 0.3738 \\
\hline Lev & 174 & 0.4181 & 0.8426 & 0.0914 & 0.1728 \\
\hline
\end{tabular}

From the results, we found no significant differences between the mean values of VAIC and MVAIC in China (2.0509 and 2.0640, respectively) and South Korea (2.3629 and 2.4555, respectively), suggesting that textile sector in both countries can efficiently utilize IC. EBITDA mean value in China was 8.2328, compared to 10.0417 in South Korea, indicating that Korea's textile companies have more earnings than those in China. Mean value of ROA was 0.0317 in China and -0.0054 in South Korea, indicating that returns on assets in China's textile sector were much higher. Mean value of ROE was 0.0467 and -0.0390 in two countries. These data indicate that investors are getting more ROE in China's textile industry. China's textile companies also had higher asset utilization than the Korean counterparts, with ATO mean value of 0.7050 and 0.9295, respectively. Regarding IC components, HCE and RCE showed great differences. It was noticeable that the mean value of HCE was the highest among IC components in the textile industry. It may be because the textile industry is regarded as the labor-intensive industry and mainly relies on labor input [29]. In addition, Size shows much difference in both countries while Lev does not. 
Table 3. Descriptive statistics of the textile industry in South Korea.

\begin{tabular}{ccccccc}
\hline Variable & N & Mean & Max & Min & Standard Deviation & Difference $t$-Statistics \\
\hline EBITDA & 185 & 10.0417 & 11.2025 & 8.2240 & 0.6003 & -29.607 \\
\hline ROA & 222 & -0.0054 & 0.3385 & -0.9912 & 0.1145 & $3.673^{* *}$ \\
\hline ROE & 222 & -0.0390 & 0.6021 & -2.0954 & 0.2885 & $3.641^{* * *}$ \\
\hline ATO & 222 & 0.9295 & 2.0500 & 0.2000 & 0.3713 & $-5.912^{*}$ \\
\hline VAIC & 222 & 2.3629 & 18.5622 & -20.1421 & 3.5096 & -0.705 \\
\hline MVAIC & 222 & 2.4555 & 18.5752 & -20.1435 & 3.4751 & -0.896 \\
\hline CEE & 222 & 0.1041 & 0.6909 & -1.8948 & 0.2823 & 5.085 \\
\hline HCE & 222 & 1.6923 & 16.9175 & -19.2976 & 3.1699 & $-0.823^{* *}$ \\
\hline SCE & 222 & 0.4739 & 12.9518 & -7.9589 & 1.5265 & -0.224 \\
\hline RCE & 222 & 0.0926 & 2.1929 & -6.7703 & 0.5412 & $-1.901^{* * *}$ \\
\hline Size & 222 & 9.1129 & 9.9881 & 8.2048 & 0.4350 & $8.665^{* *}$ \\
\hline Lev & 222 & 0.4300 & 0.9263 & 0.0617 & 0.1798 & -0.666 \\
\hline
\end{tabular}

\subsection{Correlation Analysis}

The results of correlation analysis are presented in Table 4. Results show that EBITDA, ROA, and ROE of the textile sector in these two countries were significantly positively correlated with IC (measured through VAIC and MVAIC). However, ATO was not significantly correlated with VAIC and MVAIC. The results predict that IC efficiency increases company performance in the form of higher EBITDA, ROA, and ROE and has no impact on ATO.

In the case of China's textile industry, CEE and HCE were positively correlated with EBITDA, ROA, ROE, and ATO. In panel B of Table 4, it is observed that CEE is positively correlated with the four performance indicators. 
Table 4. Correlation matrix.

\begin{tabular}{|c|c|c|c|c|c|c|c|c|c|c|c|c|}
\hline \multicolumn{13}{|c|}{ Panel A: China } \\
\hline Variable & EBITDA & ROA & ROE & ATO & VAIC & MVAIC & CEE & HCE & SCE & RCE & Size & Lev \\
\hline EBITDA & 1 & & & & & & & & & & & \\
\hline $\mathrm{ROA}$ & $0.584^{* * *}$ & 1 & & & & & & & & & & \\
\hline ROE & $0.611^{* * *}$ & $0.953^{* * *}$ & 1 & & & & & & & & & \\
\hline ATO & -0.056 & $0.201 * * *$ & $0.184^{* * *}$ & 1 & & & & & & & & \\
\hline VAIC & $0.422 * * *$ & $0.621^{* * *}$ & $0.511^{* * *}$ & 0.076 & 1 & & & & & & & \\
\hline MVAIC & $0.422 * * *$ & $0.631^{* * *}$ & $0.522 * * *$ & 0.078 & $0.993^{* * *}$ & 1 & & & & & & \\
\hline CEE & $0.394^{* * *}$ & $0.833^{* * *}$ & $0.839 * * *$ & $0.333^{* * *}$ & $0.617^{* * *}$ & $0.626^{* * *}$ & 1 & & & & & \\
\hline HCE & $0.328^{* * *}$ & $0.770^{* * *}$ & $0.711^{* * *}$ & $0.129^{* *}$ & $0.770^{* * *}$ & $0.780^{* * *}$ & $0.791 * * *$ & 1 & & & & \\
\hline SCE & $0.504^{* * *}$ & 0.020 & -0.084 & -0.053 & $0.627^{* * *}$ & $0.614^{* * *}$ & -0.022 & -0.014 & 1 & & & \\
\hline RCE & 0.041 & 0.078 & $0.176^{* *}$ & 0.041 & $-0.581^{* * *}$ & $-0.565^{* * *}$ & 0.053 & 0.027 & $-0.944^{* * *}$ & 1 & & \\
\hline Size & $0.797^{* * *}$ & $0.267^{* * *}$ & $0.237^{* * *}$ & $-0.112 *$ & $0.337^{* * *}$ & $0.337^{* * *}$ & $0.262 * * *$ & $0.252^{* * *}$ & $0.217^{* * *}$ & $-0.199^{* * *}$ & 1 & \\
\hline Lev & -0.023 & $-0.355^{* * *}$ & $-0.294^{* * *}$ & -0.035 & 0.004 & 0.001 & 0.061 & -0.066 & 0.080 & $-0.153 * *$ & $0.243^{* * *}$ & 1 \\
\hline \multicolumn{13}{|c|}{ Panel B: South Korea } \\
\hline Variable & EBITDA & ROA & ROE & ATO & VAIC & MVAIC & CEE & HCE & SCE & RCE & Size & Lev \\
\hline EBITDA & 1 & & & & & & & & & & & \\
\hline ROA & $0.393^{* * *}$ & 1 & & & & & & & & & & \\
\hline ROE & $0.416^{* * *}$ & $0.940 * * *$ & 1 & & & & & & & & & \\
\hline ATO & 0.046 & $0.187^{* * *}$ & $0.186^{* * *}$ & 1 & & & & & & & & \\
\hline VAIC & $0.440^{* * *}$ & $0.721 * * *$ & $0.647^{* * *}$ & 0.001 & 1 & & & & & & & \\
\hline MVAIC & $0.446^{* * *}$ & $0.739 * * *$ & $0.663 * * *$ & 0.004 & $0.988^{* * *}$ & 1 & & & & & & \\
\hline CEE & $0.315^{* * *}$ & $0.817^{* * *}$ & $0.877^{* * *}$ & $0.372 * * *$ & $0.550^{* * *}$ & $0.567^{* * *}$ & 1 & & & & & \\
\hline HCE & $0.419^{* * *}$ & $0.739 * * *$ & $0.652 * * *$ & -0.003 & $0.946^{* * *}$ & $0.961 * * *$ & $0.578^{* * *}$ & 1 & & & & \\
\hline SCE & $0.175^{* * *}$ & -0.051 & -0.053 & -0.068 & $0.283^{* * *}$ & $0.166^{* * *}$ & $-0.148^{* *}$ & -0.023 & 1 & & & \\
\hline $\mathrm{RCE}$ & -0.039 & 0.068 & 0.065 & 0.021 & $-0.141^{* *}$ & 0.014 & 0.078 & 0.039 & $-0.774^{* * *}$ & 1 & & \\
\hline Size & $0.752 * * *$ & $0.283^{* * *}$ & $0.280^{* * *}$ & $-0.144^{* *}$ & $0.295^{* * *}$ & $0.318^{* * *}$ & $0.241^{* * *}$ & $0.317^{* * *}$ & -0.069 & $0.128 * *$ & 1 & \\
\hline Lev & -0.070 & $-0.266^{* * *}$ & $-0.280^{* * *}$ & $0.298^{* * *}$ & $-0.234^{* * *}$ & $-0.242^{* * *}$ & $-0.102 *$ & $-0.223^{* * *}$ & -0.044 & -0.036 & 0.024 & 1 \\
\hline
\end{tabular}

Notes: ${ }^{*} p<0.10,{ }^{* *} p<0.05,{ }^{* * *} p<0.01 . t$-values are in parentheses. 


\subsection{Regression Results}

Table 5 shows the results of model (1), where the VAIC ${ }^{\mathrm{TM}}$ model was used to measure IC. Results clearly shows that VAIC has a positive and significant impact on the earnings and profitability of textile companies in China, and that VAIC has a positive and significant impact on Korean companies' performance (i.e., earnings, profitability, and productivity). The results are similar to Pal and Soriya [52] for the Indian pharmaceutical and textile industries and Smriti and Das [54] for Indian firms.

Table 5. Regression results of model (1).

\begin{tabular}{|c|c|c|c|c|c|c|c|c|}
\hline \multirow{2}{*}{ Variable } & \multicolumn{4}{|c|}{ China } & \multicolumn{4}{|c|}{ South Korea } \\
\hline & EBITDA & ROA & ROE & ATO & EBITDA & ROA & ROE & ATO \\
\hline Constant & $\begin{array}{c}-3.560^{* * *} \\
(-6.335)\end{array}$ & $\begin{array}{l}-0.250 * * \\
(-2.299)\end{array}$ & $\begin{array}{l}-0.413 * \\
(-1.926)\end{array}$ & $\begin{array}{c}2.180 * * * \\
(2.790)\end{array}$ & $\begin{array}{l}1.198^{* *} \\
(2.085)\end{array}$ & $\begin{array}{l}-0.237 \text { ** } \\
(-2.067)\end{array}$ & $\begin{array}{l}-0.734^{* *} \\
(-2.324)\end{array}$ & $\begin{array}{c}2.090 * * * \\
(4.088)\end{array}$ \\
\hline VAIC & $\begin{array}{c}0.182 * * * \\
(7.478)\end{array}$ & $\begin{array}{l}0.008^{* * *} \\
(10.158)\end{array}$ & $\begin{array}{c}0.011^{* * *} \\
(7.054)\end{array}$ & $\begin{array}{c}0.009 \\
(0.114)\end{array}$ & $\begin{array}{c}0.062 * * * \\
(5.563)\end{array}$ & $\begin{array}{l}0.022 * * * \\
(13.422)\end{array}$ & $\begin{array}{l}0.048^{* * *} \\
(10.623)\end{array}$ & $\begin{array}{l}0.014^{* *} \\
(1.981)\end{array}$ \\
\hline Size & $\begin{array}{c}1.213 \\
(19.910)\end{array}$ & $\begin{array}{c}0.036^{* * *} \\
(3.043)\end{array}$ & $\begin{array}{c}0.057^{* * *} \\
(2.468)\end{array}$ & $\begin{array}{l}-0.158 * \\
(-1.869)\end{array}$ & $\begin{array}{l}0.952 * * * \\
(14.929)\end{array}$ & $\begin{array}{l}0.023 * \\
(1.813)\end{array}$ & $\begin{array}{l}0.075^{* *} \\
(2.138)\end{array}$ & $\begin{array}{c}-0.164^{* * *} \\
(-2.879)\end{array}$ \\
\hline Lev & $\begin{array}{c}-0.573^{* * *} \\
(-4.655)\end{array}$ & $\begin{array}{c}-0.178 \\
* * * \\
(-7.410)\end{array}$ & $\begin{array}{c}-0.252 \\
* * * \\
(-5.335)\end{array}$ & $\begin{array}{c}0.004 \\
(0.023)\end{array}$ & $\begin{array}{c}-0.149 \\
(-0.919)\end{array}$ & $\begin{array}{l}-0.071 * * \\
(-2.342)\end{array}$ & $\begin{array}{c}-0.236^{* * *} \\
(-2.825)\end{array}$ & $\begin{array}{c}0.690 * * * \\
(5.109)\end{array}$ \\
\hline $\mathrm{F}$ & $172.058^{* * *}$ & $66.178^{* * *}$ & $33.507^{* * *}$ & $1.572 *$ & $\underset{* * *}{106.823}$ & $84.306^{* * *}$ & $58.775^{* * *}$ & $10.584^{* * *}$ \\
\hline Adj. $R^{2}$ & 0.768 & 0.531 & 0.360 & 0.010 & 0.633 & 0.531 & 0.440 & 0.115 \\
\hline $\mathrm{N}$ & 156 & 174 & 174 & 174 & 185 & 222 & 222 & 222 \\
\hline
\end{tabular}

When EBITDA was used as the dependent variable, the coefficient on VAIC in China $(\beta=0.182$, $t=7.478)$ was greater than that in South Korea $(\beta=0.062, t=0.062)$. This suggests that IC has a stronger impact on companies' earnings in China than in South Korea. In addition, the impact of VAIC on profitability and productivity in South Korea was greater than that in China.

Furthermore, in China and South Korea, the impact of firm size on profitability was positive, and the impact of leverage on earnings and profitability was negative. Firm size negatively affected the productivity of textile companies in both countries.

Table 6 shows the results of model (2) when the individual components of VAIC were taken as an indicator of IC. The impact of Size and Lev remained similar to the findings of Table 5. CEE was significant across all performance indicators in both countries. In the case of China, HCE had a positive impact only on ROA and negative impact on EBITDA and ATO. However, HCE positively affected textile companies' earnings and profitability and negatively affected the productivity of these companies in South Korea. In terms of SCE, SCE was significant only in the case of EBITDA and ROE for China's textile industry, and was significant only in the case of ROE in South Korea.

Table 7 shows the regression results for model (3), where MVAIC was chosen as the independent variable. In China, the estimated MVAIC coefficients were found to be statistically significant when EBITDA, ROA, and ROE were used as performance measures. In South Korea, the MVAIC coefficients were positive and significant, having values $0.016-0.063$ in all performance measures. The impact of MVAIC on earnings, profitability, and productivity in China and South Korea was similar to the results in Table 5. In addition, control variables (Size and Lev) also depict the same results as well. 
Table 6. Regression results of model (2).

\begin{tabular}{|c|c|c|c|c|c|c|c|c|}
\hline \multirow{2}{*}{ Variable } & \multicolumn{4}{|c|}{ China } & \multicolumn{4}{|c|}{ South Korea } \\
\hline & EBITDA & ROA & ROE & ATO & EBITDA & ROA & ROE & ATO \\
\hline Constant & $\begin{array}{l}-2.724^{* * *} \\
(-10.432)\end{array}$ & $\begin{array}{c}-0.225^{* * *} \\
(-4.231)\end{array}$ & $\begin{array}{c}-0.362 * * * \\
(-3.300)\end{array}$ & $\begin{array}{c}2.294^{* * *} \\
(3.214)\end{array}$ & $\begin{array}{l}1.026^{*} \\
(1.965)\end{array}$ & $\begin{array}{l}-0.096 \\
(-1.219)\end{array}$ & $\begin{array}{l}-0.364^{* *} \\
(-2.055)\end{array}$ & $\begin{array}{c}2.380 * * * \\
(5.257)\end{array}$ \\
\hline CEE & $\begin{array}{l}1.782^{* * *} \\
(21.884)\end{array}$ & $\begin{array}{l}0.254^{* * *} \\
(16.683)\end{array}$ & $\begin{array}{l}0.502^{* * *} \\
(15.964)\end{array}$ & $\begin{array}{l}1.184^{* * *} \\
(5.778)\end{array}$ & $\begin{array}{c}1.343^{* * * *} \\
(6.724)\end{array}$ & $\begin{array}{l}0.242^{* * *} \\
(15.421)\end{array}$ & $\begin{array}{l}0.782^{* * *} \\
(22.083)\end{array}$ & $\begin{array}{c}0.750 * * * \\
(8.277)\end{array}$ \\
\hline HCE & $\begin{array}{c}-0.231 * * * \\
(-7.209)\end{array}$ & $\begin{array}{c}0.003 * * * \\
(3.505)\end{array}$ & $\begin{array}{c}0.00002 \\
(0.016)\end{array}$ & $\begin{array}{c}-0.034 * * * \\
(-3.064)\end{array}$ & $\begin{array}{c}0.040^{* * *} \\
(3.255)\end{array}$ & $\begin{array}{c}0.013^{* * *} \\
(8.893)\end{array}$ & $\begin{array}{c}0.014^{* * *} \\
(4.372)\end{array}$ & $\begin{array}{c}-0.022 * * * \\
(-2.636)\end{array}$ \\
\hline SCE & $\begin{array}{l}2.001^{* * * *} \\
(14.108)\end{array}$ & $\begin{array}{c}0.001 \\
(1.591)\end{array}$ & $\begin{array}{l}-0.002 * \\
(-1.971)\end{array}$ & $\begin{array}{l}0.0001 \\
(0.012)\end{array}$ & $\begin{array}{c}0.046 \\
(1.648)\end{array}$ & $\begin{array}{c}0.003 \\
(1.325)\end{array}$ & $\begin{array}{l}0.011^{* *} \\
(2.124)\end{array}$ & $\begin{array}{c}0.002 \\
(0.182)\end{array}$ \\
\hline Size & $\begin{array}{l}1.089^{* * *} \\
(38.260)\end{array}$ & $\begin{array}{c}0.029^{* * *} \\
(4.979)\end{array}$ & $\begin{array}{c}0.043^{* * *} \\
(3.621)\end{array}$ & $\begin{array}{l}-0.187^{* *} \\
(-2.416)\end{array}$ & $\begin{array}{l}0.972^{* * *} \\
(16.791)\end{array}$ & $\begin{array}{c}0.008 \\
(0.956)\end{array}$ & $\begin{array}{l}0.036^{*} \\
(1.833)\end{array}$ & $\begin{array}{c}-0.195^{* * *} \\
(-3.881)\end{array}$ \\
\hline Lev & $\begin{array}{l}-0.773^{* * *} \\
(-12.911)\end{array}$ & $\begin{array}{l}-0.189^{* * *} \\
(-15.882)\end{array}$ & $\begin{array}{l}-0.277^{* * *} \\
(-11.266)\end{array}$ & $\begin{array}{c}-0.121 \\
(-0.755)\end{array}$ & $\begin{array}{c}-0.523^{* * *} \\
(-3.336)\end{array}$ & $\begin{array}{c}-0.079 * * * \\
(-3.886)\end{array}$ & $\begin{array}{c}-0.266^{* * *} \\
(-5.759)\end{array}$ & $\begin{array}{l}0.661^{* * * *} \\
(5.603)\end{array}$ \\
\hline F & $640.205^{* * *}$ & $277.039^{* * *}$ & $173.563^{* * *}$ & $8.325^{* * *}$ & $86.577^{* * *}$ & $163.922^{* * *}$ & $214.874^{* * *}$ & $22.232^{* * *}$ \\
\hline Adj. $R^{2}$ & 0.954 & 0.889 & 0.833 & 0.175 & 0.699 & 0.787 & 0.829 & 0.324 \\
\hline $\mathrm{N}$ & 156 & 174 & 174 & 174 & 185 & 222 & 222 & 222 \\
\hline
\end{tabular}

Table 7. Regression results of model (3).

\begin{tabular}{ccccccccc}
\hline \multirow{2}{*}{ Variable } & \multicolumn{9}{c}{ China } & \multicolumn{5}{c}{ South Korea } \\
\cline { 2 - 9 } & EBITDA & ROA & ROE & ATO & EBITDA & ROA & ROE & ATO \\
\hline \multirow{2}{*}{ Constant } & $-3.581^{* * * *}$ & $-0.244^{*}$ & $-0.400^{*}$ & $2.187^{* * *}$ & $1.222^{* *}$ & $-0.189^{*}$ & $-0.628^{* *}$ & $2.140^{* * *}$ \\
& $(-6.405)$ & $(-2.262)$ & $(-1.882)$ & $(2.800)$ & $(2.116)$ & $(-1.670)$ & $(-2.003)$ & $(4.166)$ \\
\hline \multirow{2}{*}{ MVAIC } & $0.184^{* * *}$ & $0.009^{* * *}$ & $0.012^{* * *}$ & 0.010 & $0.063^{* * *}$ & $0.023^{* * *}$ & $0.050^{* * *}$ & $0.016^{* * *}$ \\
& $(7.614)$ & $(10.450)$ & $(7.278)$ & $(1.616)$ & $(5.462)$ & $(14.101)$ & $(11.063)$ & $(2.163)$ \\
\hline \multirow{2}{*}{ Size } & $1.214^{* * *}$ & $0.035^{* * *}$ & $0.056^{* *}$ & $-0.159^{*}$ & $0.948^{* * *}$ & 0.017 & $0.062^{*}$ & $-0.170^{* * *}$ \\
& $(20.040)$ & $(3.004)$ & $(2.419)$ & $(-1.879)$ & $(14.763)$ & $(1.345)$ & $(1.762)$ & $(-2.973)$ \\
\hline \multirow{2}{*}{ Lev } & $-0.565^{* * *}$ & $-0.176^{* * *}$ & $-0.250^{* * *}$ & $0.005^{* *}$ & -0.141 & $-0.063^{* *}$ & $-0.219^{* * *}$ & $0.700^{* * *}$ \\
& $(-4.608)$ & $\left(-7.433^{* *}\right.$ & $(-5.329)$ & $(0.032)$ & $(-0.860)$ & $(-2.133)$ & $(-2.656)$ & $(5.172)$ \\
\hline F & $174.253^{* * *}$ & $68.887^{* * *}$ & $34.823^{* * *}$ & $1.603^{*}$ & $105.948^{* * *}$ & $91.674^{* * *}$ & $62.566^{* * *}$ & $10.867^{* * *}$ \\
\hline \multirow{2}{*}{ Adj. $\mathrm{R}^{2}$} & 0.770 & 0.541 & 0.370 & 0.010 & 0.631 & 0.552 & 0.455 & 0.118 \\
\hline $\mathrm{N}$ & 156 & 174 & 174 & 174 & 185 & 222 & 222 & 222 \\
\hline
\end{tabular}

Notes: ${ }^{*} p<0.10,{ }^{* *} p<0.05,{ }^{* * *} p<0.01 . t$-values are in parentheses.

Table 8 presents the regression results for model (4), where RCE was introduced as a proxy for IC components. Regarding the impact of individual components of MVAIC, the CEE coefficients were statistically significant, positive and higher than other HCE, SCE, and RCE coefficients in the ROA, ROE, and ATO indicators in the two countries. Furthermore, in the context of South Korea, HCE had a positive impact on EBITDA, ROA, and ROE, while HCE only had a positive effect on ROA in China. Interestingly, HCE had a negative impact on ATO measure. SCE positively influenced the profitability of textile companies in both countries. RCE had a positive impact on both ROA and ROE in China, while it had a positive impact only on ROE in South Korea. Control variables (Size and Lev) showed similar coefficients as in the case of previous results.

In conclusion, these findings extend Malinowska-Olszowy's [16,17], Sivalogathasan and Wu's [18], and Pal and Soriya's [52] findings about IC research in the textile industry. 
Table 8. Regression results of model (4).

\begin{tabular}{|c|c|c|c|c|c|c|c|c|}
\hline \multirow{2}{*}{ Variable } & \multicolumn{4}{|c|}{ China } & \multicolumn{4}{|c|}{ South Korea } \\
\hline & EBITDA & ROA & ROE & ATO & EBITDA & ROA & ROE & ATO \\
\hline Constant & $\begin{array}{l}-2.775^{* * * *} \\
(-10.513)\end{array}$ & $\begin{array}{c}-0.220^{* * *} \\
(-4.436)\end{array}$ & $\begin{array}{c}-0.353^{* * *} \\
(-3.380)\end{array}$ & $\begin{array}{c}2.275^{* * *} \\
(3.195)\end{array}$ & $\begin{array}{l}0.998^{*} \\
(1.898)\end{array}$ & $\begin{array}{c}-0.084 \\
(-1.072)\end{array}$ & $\begin{array}{l}-0.333^{*} \\
(-1.888) \\
\end{array}$ & $\begin{array}{c}2.418^{* * *} \\
(5.319)\end{array}$ \\
\hline CEE & $\begin{array}{l}1.768^{* * * *} \\
(21.527)\end{array}$ & $\begin{array}{l}0.243^{* * *} \\
(16.884)\end{array}$ & $\begin{array}{l}0.482^{* * *} \\
(15.901)\end{array}$ & $\begin{array}{c}1.227^{* * *} \\
(5.933)\end{array}$ & $\begin{array}{c}1.345^{* * * *} \\
(6.721)\end{array}$ & $\begin{array}{l}0.245^{* * *} \\
(15.569)\end{array}$ & $\begin{array}{l}0.790^{* * *} \\
(22.305)\end{array}$ & $\begin{array}{c}0.759 * * * \\
(8.328)\end{array}$ \\
\hline HCE & $\begin{array}{l}-0.227^{* * *} \\
(-7.079)\end{array}$ & $\begin{array}{l}0.003^{* * *} \\
(4.342)\end{array}$ & $\begin{array}{c}0.001 \\
(0.524)\end{array}$ & $\begin{array}{l}-0.036^{* * *} \\
(-3.211)\end{array}$ & $\begin{array}{c}0.039^{* * *} \\
(3.201)\end{array}$ & $\begin{array}{l}0.013^{* * * *} \\
(8.877)\end{array}$ & $\begin{array}{l}0.014^{* * *} \\
(4.342)\end{array}$ & $\begin{array}{c}-0.022^{* * *} \\
(-2.661)\end{array}$ \\
\hline SCE & $\begin{array}{l}1.980^{* * *} \\
(13.884)\end{array}$ & $\begin{array}{l}0.009 * * * \\
(5.405)\end{array}$ & $\begin{array}{c}0.012^{* * * *} \\
(3.368)\end{array}$ & $\begin{array}{l}-0.031 \\
(-1.279)\end{array}$ & $\begin{array}{c}0.032 \\
(0.865)\end{array}$ & $\begin{array}{l}0.008^{* *} \\
(2.118)\end{array}$ & $\begin{array}{l}0.024^{* * *} \\
(2.851)\end{array}$ & $\begin{array}{c}0.018 \\
(0.848)\end{array}$ \\
\hline $\mathrm{RCE}$ & $\begin{array}{c}0.330 \\
(1.230) \\
\end{array}$ & $\begin{array}{c}0.244^{* * *} \\
(5.129)\end{array}$ & $\begin{array}{c}0.429^{* * *} \\
(4.280)\end{array}$ & $\begin{array}{c}-0.929 \\
(-1.357) \\
\end{array}$ & $\begin{array}{c}-0.084 \\
(-0.573) \\
\end{array}$ & $\begin{array}{c}0.017 \\
(0.101) \\
\end{array}$ & $\begin{array}{l}0.046^{*} \\
(1.938) \\
\end{array}$ & $\begin{array}{c}0.058 \\
(0.943) \\
\end{array}$ \\
\hline Size & $\begin{array}{l}1.094^{* * *} \\
(38.124)\end{array}$ & $\begin{array}{l}0.027^{* * *} \\
(5.011)\end{array}$ & $\begin{array}{c}0.040^{* * *} \\
(3.529)\end{array}$ & $\begin{array}{l}-0.180^{* *} \\
(-2.333)\end{array}$ & $\begin{array}{l}0.978^{* * *} \\
(16.602)\end{array}$ & $\begin{array}{c}0.006 \\
(0.735)\end{array}$ & $\begin{array}{c}0.031 \\
(1.574)\end{array}$ & $\begin{array}{l}-0.201^{* * *} \\
(-3.971)\end{array}$ \\
\hline Lev & $\begin{array}{l}-0.761^{* * *} \\
(-12.553)\end{array}$ & $\begin{array}{l}-0.173^{* * *} \\
(-15.035)\end{array}$ & $\begin{array}{l}-0.249 * * * \\
(-10.250)\end{array}$ & $\begin{array}{l}-0.181 \\
(-1.094)\end{array}$ & $\begin{array}{c}-0.543^{* * *} \\
(-3.375)\end{array}$ & $\begin{array}{l}-0.075^{* * *} \\
(-3.684)\end{array}$ & $\begin{array}{c}-0.255^{* * *} \\
(-5.531)\end{array}$ & $\begin{array}{c}0.674 * * * \\
(5.673)\end{array}$ \\
\hline F & $535.578^{* * *}$ & $270.026^{* * *}$ & $162.595^{* * *}$ & $7.279^{* * *}$ & $71.931^{* * *}$ & $138.139^{* * *}$ & $181.973^{* * *}$ & $18.665^{* * *}$ \\
\hline Adj. $R^{2}$ & 0.954 & 0.903 & 0.849 & 0.179 & 0.698 & 0.788 & 0.831 & 0.324 \\
\hline $\mathrm{N}$ & 156 & 174 & 174 & 174 & 185 & 222 & 222 & 222 \\
\hline
\end{tabular}

\section{Discussion}

The aim of this study was to analyze and compare the impact of IC and its sub-components on the performance of textile companies in two emerging markets (China and South Korea) during 2012-2017.

Findings from models (1) and (3) suggest that IC positively affects all performance indicators in the Korean textile sector. However, in the case of China, we find that IC has a positive impact only on companies' earnings and profitability. The results are similar to the findings by Smriti and Das [54] who found a positive relation between IC and ATO, ROA, Tobin's Q, and sales growth rate. Sardo and Serrasqueiro [34] also stated IC can improve firms' financial performance and generate great wealth in developing countries. Therefore, $\mathrm{H} 1$ and $\mathrm{H} 2$ are supported and $\mathrm{H} 3$ is partially supported.

In Tables 5 and 7, we found that the impact of IC on companies' earnings in China is greater than that in South Korea, and that the impact of IC on profitability and productivity in China is lower than that in South Korea. This indicates that South Korea has proven itself to have a strong and resilient economy that may help it step up to become more advanced in the near future. Therefore, $\mathrm{H} 4 \mathrm{a}, \mathrm{H} 4 \mathrm{~b}$, and $\mathrm{H} 4 \mathrm{c}$ are fully supported.

Considering companies' earnings, findings of models (2) and (4) clearly show that CEE and SCE have a positive impact on the EBITDA of Chinese textile companies, with SCE contributing the most. HCE is observed to have a significant but negative impact on companies' earnings in China, suggesting that investors fail to recognize the importance of human resources in the form of employees' knowledge, aptitude, and skills [72,73]. This is due to the fact that China is undergoing great economic transformation from export- and investment-led to consumption- and innovation-driven, and structural change and industrial upgrading brings new opportunities for achieving sustainable growth [74,75]. In the Korean context, CEE and HCE has a positive impact, with CEE contributing the most. Dzenopoljac et al. [53], based on the data of 100 Arab companies, found that companies' earnings are determined by physical capital and SC. However, Maditinos et al. [76] failed to verify that firms with greater IC generate more revenue.

In terms of profitability, CEE, SCE, and RCE have a significant and positive influence on ROA and ROE when applying the MVAIC ${ }^{\mathrm{TM}}$ model. The adjusted $\mathrm{R}^{2}$ in the MVAIC ${ }^{\mathrm{TM}}$ model $(90.3$ percent and 84.9 percent) are much higher than those in the VAIC ${ }^{\mathrm{TM}}$ model (54.1 percent and 37.0 percent), indicating that the MVAIC ${ }^{\mathrm{TM}}$ model has better explanatory power than the VAIC ${ }^{\mathrm{TM}}$ model. It is well noticing that RC can enhance the profitability of Chinese textile companies. This is because that good 
relationships with customers in China where guanxi plays an important role in Chinese culture can enable companies to build company's reputation and gain customers' loyalty [77,78]. However, in Korea, the analysis shows that corporate profitability is positively correlated with only CEE, HCE, and SCE. Xu and Wang [6] confirmed that CEE, HCE, and RCE positively affect financial performance of Korean manufacturing companies with RCE contributing the most. Andreeva and Garanina [79] found that $\mathrm{HC}$ and SC positively influence the performance of Russian manufacturing companies, while RC does not.

Concerning companies' productivity, the regression results of models (2) and (4) show that ATO is positively correlated only by the CEE of textile companies in both countries, whereas ATO has a negative relation with HCE. This is not in line with the finding of Chen et al. [51] who found a positive relationship between ATO, HCE and SCE; Dzenopoljac et al. [53] who found that the only factor affecting companies' productivity is physical capital; and Smriti and Das [54] who observed a negative relationship between CEE and ATO and a positive relationship between HCE and SCE and ATO. This implies that investors were still reluctant to invest in human assets during China's economic transformation.

Overall, CEE, SCE, and RCE are found to be the main value-added drivers for Chinese textile companies. In South Korea, CEE and HCE are major contributors to the performance of the textile industry.

\section{Conclusions}

This study, using the VAIC ${ }^{\mathrm{TM}}$ and MVAIC ${ }^{\mathrm{TM}}$ model, aims to examine the impact of IC and its sub-components on firm performance in textile industry between China and South Korea. The results provide a full explanation of how the textile industry creates a productive process for sustainable development by effectively utilizing IC. The main conclusions are as follows:

(1) IC is a driving force of enhancing firm earnings, profitability, and productivity for the textile industry in China and South Korea.

(2) Development of the textile industry in China relies on CEE, SCE, and RCE. CEE makes the largest contribution in the performance of China's textile companies. However, HCE cannot foster company's performance in the textile industry on a sustainable basis.

(3) In South Korea, the contribution of CEE is the largest, followed by HCE and SCE, among IC sub-components. RCE has no impact on any performance indicator.

(4) The impact of IC on company earnings in China is greater than that in South Korea, while the impact of IC on profitability and productivity in China is lower than that in South Korea

Theoretical implication of this study is its position as the first study to examine IC performance of the textile industry in China and South Korea by employing the VAIC ${ }^{\mathrm{TM}}$ and MVAIC ${ }^{\mathrm{TM}}$ model and comprehensive multidimensional IC indicators (i.e., physical capital, HC, SC, and RC). It can also be a base study for future research exploring IC performance of other traditional industries in other countries or regions.

Some practical implications are put forward as follows:

(1) Considering the positive relation between the aggregate IC and firm performance, managers should increase the awareness on the significance of IC and focus on the overall IC including physical capital, HC, SC, and RC which act as important inputs for corporate success. In addition, companies should also reasonably invest in different components of IC due to their limited resources.

(2) Faced with the "Supply-side Structural Reform" policy, China's textile companies should take advantage of their social networks, gain advanced skills, and grasp market opportunities. In this way, the sustainable development of China's textile industry will be finally realized. In addition, managers should invest in upgrading skills, knowledge, and innovational capabilities of human resources to improve their HCE.

(3) Managers of Korea's textile companies should pay great attention to developing their SC. They should have a clear knowledge strategy, implement information systems and tools, utilize internal 
resources and corporate process, and invest more in R\&D activities, which in turn will enhance the innovation in product and process. Meanwhile, they should keep close ties with their customers and suppliers.

(4) Textile companies also need to cooperate with the local government [70]. With the support of the local government, textile companies should accelerate institutional innovation and technological innovation. Shah [80] and Nadeem et al. [81] believed that government must provide tax incentives to bring more innovation in products.

When the data of other emerging economies are used, it will help us analyze IC performance of the textile industry in emerging markets more accurately. Furthermore, some macroeconomic factors (e.g., gross domestic product and consumer price index) should be added into the analysis, which will be done in the future.

Author Contributions: Conceptualization, J.X.; methodology, J.X. and B.W.; data curation, J.X.; writing—original draft preparation, J.X. and B.W.; writing-review and editing, J.X. and B.W.

Funding: This research received no external funding.

Acknowledgments: We would like to thank the editor and the anonymous reviewers for their useful comments on earlier drafts.

Conflicts of Interest: The authors declare no conflict of interest.

\section{References}

1. Petty, R.; Guthrie, J. Intellectual capital literature review: Measurement, reporting and management. J. Intellect. Cap. 2000, 1, 155-176. [CrossRef]

2. Cañibano, L.; García-Ayuso, M.; Sánchez, P. Accounting for intangibles: A literature review. J. Account. Lit. 2000, 19, 102-130.

3. Goh, P.C. Intellectual capital performance of commercial banks in Malaysia. J. Intellect. Cap. 2005, 6, 385-396.

4. Holland, J. Fund management, intellectual capital, intangibles and private disclosure. Manag. Financ. 2006, 32, 277-316. [CrossRef]

5. Phusavat, K.; Comepa, N.; Sitko-Lutek, A.; Ooi, K.-B. Interrelationships between intellectual capital and performance: Empirical examination. Ind. Manag. Data Syst. 2011, 111, 810-829. [CrossRef]

6. $\mathrm{Xu}, \mathrm{J} . ;$ Wang, B. Intellectual capital, financial performance and companies' sustainable growth: Evidence from the Korean manufacturing industry. Sustainability 2018, 10, 4651. [CrossRef]

7. Vidyarthi, H. Dynamics of intellectual capitals and bank efficiency in India. Serv. Ind. J. 2019, 39, 1-24. [CrossRef]

8. Bhasin, M.L. Measurement and disclosure of intellectual capital in a developing country: An exploratory study. Aust. J. Bus. Manag. Res. 2012, 2, 63-75.

9. Forte, W.; Tucker, J.; Matonti, G.; Nicolò, G. Measuring the intellectual capital of Italian listed companies. J. Intellect. Cap. 2017, 18, 710-732. [CrossRef]

10. Ujwary-Gil, A. The business model and intellectual capital in the value creation of firms: A literature review. Balt. J. Manag. 2017, 12, 368-386. [CrossRef]

11. Ahi, P.; Searcy, C.; Jaber, M.Y. A quantitative approach for assessing sustainability performance of corporations. Ecol. Econ. 2018, 152, 336-346. [CrossRef]

12. Cantele, S.; Zardini, A. Is sustainability a competitive advantage for small businesses? An empirical analysis of possible mediators in the sustainability-financial performance relationship. J. Clean Prod. 2018, 182, 166-176. [CrossRef]

13. Hussain, N.; Rigoni, U.; Cavezzali, E. Does it pay to be sustainable? Looking inside the black box of the relationship between sustainability performance and financial performance. Corp. Soc. Responsib. Environ. Manag. 2018, 25, 1198-1211. [CrossRef]

14. Tseng, M.-L.; Lim, M.K.; Wu, K.-J. Corporate sustainability performance improvement using an interrelationship hierarchical model approach. Bus. Strateg. Environ. 2018, 27, 1334-1346. [CrossRef]

15. Hussain, T.; Edgeman, R.; Eskildsen, J.; Shoukry, A.M.; Gani, S. Sustainable enterprise excellence: Attribute-based assessment protocol. Sustainability 2018, 10, 4097. [CrossRef] 
16. Malinowska-Olszowy, M. The choice of appropriate tools for measuring intellectual capital as a determinant of success with special emphasis on the textile and clothing market. Autex Res. J. 2013, 13, 122-127. [CrossRef]

17. Malinowska-Olszowy, M. Importance of intellectual capital in enterprise growth, with special emphasis on the textile and clothing industry in Poland. Fibres Text. East. Eur. 2012, 20, 10-15.

18. Sivalogathasan, $\mathrm{V}$; $\mathrm{Wu}, \mathrm{X}$. Impact of organization motivation on intellectual capital and innovation capability of the textile and apparel industry in Sri Lanka. Int. J. Innov. Sci. 2015, 7, 153-165. [CrossRef]

19. Zheng, J.; Zheng, R. A comparative analysis of cotton textile industry between China and South Korea. China Text. 2014, 10, 20-21.

20. McNamara, D. Market and Society in Korea: Interest, Institution and the Textile Industry; Routledge: New York, NY, USA, 2002.

21. Lee, C.-K.; Sohn, S.-S. Multiplier decomposition in the textile industry among Korea, China and Japan: Focused on the world input-output table. J. Korean Natl. Econ. 2016, 34, 105-128.

22. Lau, C.K.; To, K.M.; Zhang, Z.M.; Chen, J. Determinants of competitiveness: Observations in China's textile and apparel industries. China World Econ. 2009, 17, 45-64. [CrossRef]

23. Peng, L.H.; Zhang, Y.T.; Wang, Y.J.; Zeng, X.L.; Peng, N.J.; Yu, A. Energy efficiency and influencing factor analysis in the overall Chinese textile industry. Energy 2015, 93, 1222-1229. [CrossRef]

24. Zhang, J.L.; Liu, Y.Y.; Cheng, L.D. Structural changes and growth factors of China's textile industry: 1997-2012. Fibres Text. East. Eur. 2018, 26, 20-25. [CrossRef]

25. Wang, J. Institutional Change and the Development of Industrial Clusters in China: Case Studies from Textile and Clothing Industry; World Scientific: Singapore, 2013.

26. Zhang, Z.; To, C.; Cao, N. How do industry clusters succeed: A case study in China's textile and apparel industries. J. Text. Apparel Technol. Manag. 2004, 4, 1-10.

27. Huang, B.J.; Zhao, J.; Geng, Y.; Tian, Y.H.; Jiang, P. Energy-related GHG emissions of the textile industry in China. Resour. Conserv. Recycl. 2017, 119, 69-77. [CrossRef]

28. Xu, C.K.; Cheng, H.; Liao, Z.J. Towards sustainable growth in the textile industry: A case study of environmental policy in China. Pol. J. Environ. Stud. 2018, 27, 2325-2336. [CrossRef]

29. Lin, B.Q.; Chen, Y.; Zhang, G.L. Impact of technological progress on China's textile industry and future energy saving potential forecast. Energy 2018, 161, 859-869. [CrossRef]

30. Yue, J.B. The development of textile industry in China under the background of "One Belt And One Road". Text. Rep. 2018, 37, 43-44. (In Chinese)

31. Human Resource Costs. Available online: http://www.dgfez.net/eng/page.php?mnu_uid=356\& (accessed on 26 February 2019).

32. Wang, M.-C. Value relevance on intellectual capital valuation methods: The role of corporate governance. Qual. Quant. 2013, 47, 1213-1223. [CrossRef]

33. Khalique, M.; Bontis, N.; bin Shaari, J.A.N.; Isa, A.H.M. Intellectual capital in small and medium enterprises in Pakistan. J. Intellect. Cap. 2015, 16, 224-238. [CrossRef]

34. Sardo, F.; Serrasqueiro, Z. Intellectual capital, growth opportunities, and financial performance in European firms: Dynamic panel data analysis. J. Intellect. Cap. 2018, 19, 747-767. [CrossRef]

35. Stewart, T.A. Intellectual Capital: The New Wealth of Organizations; Doubleday: New York, NY, USA, 1997.

36. Sullivan, P.H. Value-Driven Intellectual Capital: How to Convert Intangible Corporate Assets into Market Value; John Wiley \& Sons, Inc.: New York, NY, USA, 2000.

37. Bontis, N.; Fitz-enz, J. Intellectual capital ROI: A causal map of human capital antecedents and consequents. J. Intellect. Cap. 2002, 3, 223-247. [CrossRef]

38. St-Pierre, J.; Audet, J. Intangible assets and performance: Analysis on manufacturing SMEs. J. Intellect. Cap. 2011, 12, 202-223. [CrossRef]

39. Henry, L. Intellectual capital in a recession: Evidence from UK SMEs. J. Intellect. Cap. 2013, 14, 84-101. [CrossRef]

40. Cohen, S.; Naoum, V.C.; Vlismas, O. Intellectual capital, strategy and financial crisis from a SMEs perspective. J. Intellect. Cap. 2014, 15, 294-315. [CrossRef]

41. Asiaei, K.; Jusoh, R. Using a robust performance measurement system to illuminate intellectual capital. Int. J. Account. Inf. Syst. 2017, 25, 1-19. [CrossRef]

42. Rodov, I.; Leliaert, P. FiMIAM: Financial method of intangible assets measurement. J. Intellect. Cap. 2002, 3, 323-336. [CrossRef] 
43. Krstić, B.; Bonić, L. EIC: A new tool for intellectual capital performance measurement. Prague Econ. Pap. 2016, 25, 723-740. [CrossRef]

44. Edvinsson, L.; Malone, M.S. Intellectual Capital: Realizing Your Company's True Value by Finding Its Hidden Brainpower; Harper Business: New York, NY, USA, 1997.

45. Sveiby, K.E. The New Organizational Wealth: Managing and Measuring Knowledge-Based Assets; Berrett-Koehler Publishers: San Francisco, CA, USA, 1997.

46. Kaplan, R.S.; Norton, D.P. The Balanced Scorecard: Translating Strategy into Action; Harvard Business Press: Boston, MA, USA, 1996.

47. Pulic, A. Measuring the Performance of Intellectual Potential in Knowledge Economy, 2nd ed.; McMaster World Congress on Measuring and Managing Intellectual Capital: Hamilton, ON, Canada, 1998.

48. Pulic, A. VAIC ${ }^{\mathrm{TM}}$ _An accounting tool for IC management. Int. J. Technol. Manag. 2000, 20, 702-714. [CrossRef]

49. Brooking, A. Intellectual Capital: Core Asset for the Third Millennium Enterprise; International Thomson Publishing: London, UK, 1996.

50. Firer, S.; Williams, M. Intellectual capital and traditional measures of corporate performance. J. Intellect. Cap. 2003, 4, 348-360. [CrossRef]

51. Chen, M.C.; Cheng, S.J.; Hwang, Y. An empirical investigation of the relationship between intellectual capital and firms' market value and financial performance. J. Intellect. Cap. 2005, 6, 159-176. [CrossRef]

52. Pal, K.; Soriya, S. IC performance of Indian pharmaceutical and textile industry. J. Intellect. Cap. 2012, 13, 120-137. [CrossRef]

53. Dzenopoljac, V.; Yaacoub, C.; Elkanj, N.; Bontis, N. Impact of intellectual capital on corporate performance: Evidence from the Arab region. J. Intellect. Cap. 2017, 18, 884-903. [CrossRef]

54. Smriti, N.; Das, N. The impact of intellectual capital on firm performance: A study of Indian firms listed in COSPI. J. Intellect. Cap. 2018, 19, 935-964. [CrossRef]

55. Nimtrakoon, $\mathrm{S}$. The relationship between intellectual capital, firms' market value and financial performance: Empirical evidence from the ASEAN. J. Intellect. Cap. 2015, 16, 587-618. [CrossRef]

56. Ståhle, P.; Ståhle, S.; Aho, S. Value added intellectual coefficient (VAIC): A critical analysis. J. Intellect. Cap. 2011, 12, 531-551. [CrossRef]

57. Iazzolino, G.; Laise, D. Value added intellectual coefficient (VAIC): A methodological and critical review. J. Intellect. Cap. 2013, 14, 547-563. [CrossRef]

58. Montequín, V.R.; Fernández, F.O.; Cabal, V.A.; Gutierrez, N.R. An integrated framework for intellectual capital measurement and knowledge management implementation in small and medium-sized enterprises. J. Inf. Sci. 2006, 32, 525-538. [CrossRef]

59. Janošević, S.; Dženopoljac, V.; Bontis, N. Intellectual capital and financial performance in Serbia. Knowl. Process Manag. 2013, 20,1-11.

60. Jordão, R.V.D.; de Almeida, V.R. Performance measurement, intellectual capital and financial sustainability. J. Intellect. Cap. 2017, 18, 643-666. [CrossRef]

61. Xu, J.; Wang, B. Intellectual capital and financial performance of Chinese agricultural listed companies. Custos Agronegocio Line 2019, 15, 273-290.

62. Bontis, N.; Keow, W.C.C.; Richardson, S. Intellectual capital and business performance in Malaysian industries. J. Intellect. Cap. 2000, 1, 85-100. [CrossRef]

63. Wang, W.Y.; Chang, C. Intellectual capital and performance in causal models: Evidence from the information technology industry in Taiwan. J. Intellect. Cap. 2005, 6, 222-236. [CrossRef]

64. Yalama, A.; Coskun, M. Intellectual capital performance of quoted banks on the Istanbul stock exchange market. J. Intellect. Cap. 2007, 8, 256-271. [CrossRef]

65. Sardo, F.; Serrasqueiro, Z.; Alves, H. On the relationship between intellectual capital and financial performance: A panel data analysis on SME hotels. Int. J. Hosp. Manag. 2018, 75, 67-74. [CrossRef]

66. Gan, K.; Saleh, Z. Intellectual capital and corporate performance of technology-intensive companies: Malaysia evidence. Asian J. Bus. Account. 2008, 1, 113-130.

67. Firer, S.; Stainbank, L. Testing the relationship between intellectual capital and a company's performance: Evidence from South Africa. Meditori Account. Res. 2003, 11, 25-44. [CrossRef]

68. Shiu, H.J. Application of the value added intellectual coefficient to measure corporate performance: Evidence from technological firms. Int. J. Manag. 2006, 23, 356-364. 
69. Lin, C.Y.Y.; Edvinsson, L.; Chen, J.; Beding, T. National Intellectual Capital and the Financial Crisis in Brazil, Russia, India, China, Korea, and South Africa; Springer: New York, NY, USA, 2013.

70. Bontis, N. Intellectual capital: An exploratory study that develops measures and models. Manag. Decis. 1998, 36, 63-76. [CrossRef]

71. Anghel, I.; Siminică, M.; Cristea, M.; Sichigea, M.; Noja, G.G. Intellectual capital and financial performance of biotech companies in the pharmaceutical industry. Amfiteatru Econ. 2018, 20, 631-646. [CrossRef]

72. Claver-Cortés, E.; Zaragoza-Sáez, P.C.; Molina-Manchón, H.; Úbeda-García, M. Intellectual capital in family firms: Human capital identification and measurement. J. Intellect. Cap. 2015, 16, 199-223. [CrossRef]

73. Intarakumnerd, P. Human resource management and coordination for innovative activities in production networks in Asia: A synthesis. Asian J. Technol. Innov. 2017, 25, 199-205. [CrossRef]

74. Li, K.; Lin, B. Economic growth model, structural transformation, and green productivity in China. Appl. Energy 2017, 187, 489-500. [CrossRef]

75. Xiao, W.; Pan, J.-D.; Liu, L.-Y. China's industrial structure upgrade in the "new normal": Empirical test and determinants. Singap. Econ. Rev. 2018, 63, 1037-1058. [CrossRef]

76. Maditinos, D.; Chatzoudes, D.; Tsairidis, C.; Therious, G. The impact of intellectual capital on firms' market value and financial performance. J. Intellect. Cap. 2011, 12, 132-151. [CrossRef]

77. Ordóñez de Pablos, P. The importance of relational capital in service industry: The case of the Spanish banking sector. Int. J. Learn. Intellect. Cap. 2004, 1, 431-440. [CrossRef]

78. Lee, L.W.Y.; Tang, Y.M.; Yip, L.S.C.; Sharma, P. Managing customer relationships in the emerging markets-guanxi as a driver of Chinese customer loyalty. J. Bus. Res. 2018, 86, 356-365. [CrossRef]

79. Andreeva, T.; Garanina, T. Do all elements of intellectual capital matter for organizational performance? Evidence from Russian context. J. Intellect. Cap. 2016, 17, 397-412. [CrossRef]

80. Shah, A. Fiscal Incentives for Investment and Innovation. Available online: http://ssrn.com/abstract=896144 (accessed on 28 January 2019).

81. Nadeem, M.; Gan, C.; Nguyen, C. Does intellectual capital efficiency improve firm performance in BRICS economies? A dynamic panel estimation. Meas. Bus. Excell. 2017, 21, 65-85. [CrossRef]

(C) 2019 by the authors. Licensee MDPI, Basel, Switzerland. This article is an open access article distributed under the terms and conditions of the Creative Commons Attribution (CC BY) license (http://creativecommons.org/licenses/by/4.0/). 